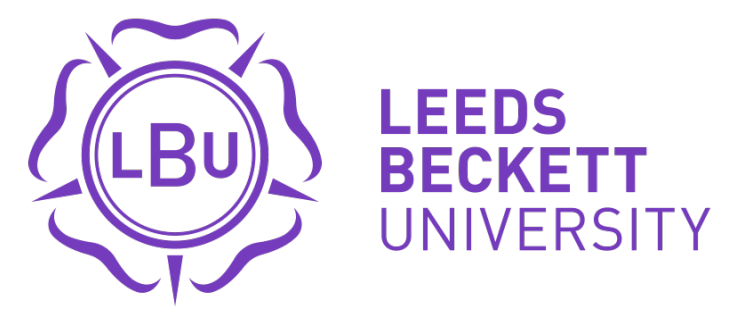

Citation:

Brown, FC and Beresin, A and Henricks, T and Meckley, A and Patte, M (2017) Brian Sutton-Smith Memorial Panel - A Celebration of the Life and Works of Brian Sutton-Smith. International Journal of Play, 6 (1). ISSN 2159-4937 DOI: https://doi.org/10.1080/21594937.2017.1288377

Link to Leeds Beckett Repository record:

https://eprints.leedsbeckett.ac.uk/id/eprint/5350/

Document Version:

Article (Accepted Version)

This is an Accepted Manuscript of an article published by Taylor \& Francis in International Journal of Play on 14 February 2017, available online: http://www.tandfonline.com/10.1080/21594937.2017.1288377

The aim of the Leeds Beckett Repository is to provide open access to our research, as required by funder policies and permitted by publishers and copyright law.

The Leeds Beckett repository holds a wide range of publications, each of which has been checked for copyright and the relevant embargo period has been applied by the Research Services team.

We operate on a standard take-down policy. If you are the author or publisher of an output and you would like it removed from the repository, please contact us and we will investigate on a case-by-case basis.

Each thesis in the repository has been cleared where necessary by the author for third party copyright. If you would like a thesis to be removed from the repository or believe there is an issue with copyright, please contact us on openaccess@leedsbeckett.ac.uk and we will investigate on a case-by-case basis. 


\title{
Brian Sutton-Smith Memorial Panel \\ - a celebration of the life and works of Brian Sutton-Smith
}

\author{
Fraser Brown - Convenor
}

(Received $1^{\text {st }}$ November 2016; approved)

\begin{abstract}
On the final day of the 2015 TASP conference, we heard of the sad passing of our great friend and inspiration, Brian Sutton-Smith. The memorial panel, which was one of the centre-pieces of the 2016 TASP conference, was the first opportunity we had to mark his passing. We did so with a selection of memories and reflections on his life. Brian spent his adult life studying the phenomenon of play in all its forms: child and adult; frivolous and serious; sporting and educational; charming and disgusting. He showed that children are not always innocent in their play, and that adults often feel guilty about theirs. His academic legacy lies in hundreds of articles and over fifty books, including the seminal work The Ambiguity of Play (1997). However, those of us who knew him well also remember the great joy with which he lived his life. The Panel was a mixture of friends, collaborators, ex-students and TASP colleagues. All of them had a story to tell about the way this great supporter of TASP touched their lives.
\end{abstract}

Keywords: ambiguity, play, Sutton-Smith

\section{The Panel}

Fraser Brown (Convenor) - Leeds Beckett University, UK

Anna Beresin - The University of the Arts, Philadelphia, USA

Tom Henricks - Elon University, North Carolina, USA

Alice Meckley - Millersville University of Pennsylvania, USA

Michael Patte - Bloomsburg University of Pennsylvania, USA

\section{Alice M. Meckley's Journey - Knowing Brian Sutton-Smith}

Brian Sutton-Smith was part of my life for 27 years. He was my teacher, my thesis advisor, my mentor, a research partner, and my friend. I miss him very much. In the past year I have read a great deal of his writings and reflected on the import of his work and life. Today, let me share some highlights of my journey knowing Brian.

My discipline is early childhood education. Throughout my career, I have remained committed to the topics of learning, teaching, young children, and play. Early in my career as an undergraduate and then a teacher, I discovered Brian Sutton-Smith as one of the writers in early childhood education who substantiated the value of play for a child's development. Much later in my career, searching for a rigorous doctoral program that would support my passion for children and play, I found the University of Pennsylvania (Penn) AND Brian Sutton-Smith. Even though I knew of his scholarly work, I still thought Brian would be one of several excellent professors at Penn. But Brian was a professor par excellence as:

- a great thinker and scholar across many disciplines and many forms of play;

- an excellent, energetic and exuberant teacher;

- a rigorous mentor as the grand playmaster; and

- a caring and empathetic thesis advisor. 
To journey with Brian the scholar in the pursuit of play, I traveled, as a student, through the literature in every imaginable discipline; I traveled around the lexicon pathways, learning about the varied forms of play including play fighting, deep play, and animal play; I traveled into the vast world of play, discovering play as part of one's lifespan not simply part of one's childhood. And I really traveled, to Paris, to present at the joint conference of ICCP and TASP, because Brian recommended that I share my research and meet international scholars. In Paris, I was introduced to both ICCP (International Council for Children's Play) and TASP (The Association for the Study of Play), organizations to become important to my scholarship.

Brian's scholarly journeys were involved and ongoing; he never stopped thinking, writing, questioning, prodding himself and others. His queries seemed endless. The breadth of his knowledge about play was mind-bending. His play knowledge was not only comprehensive but across many disciplines.

Brian Sutton-Smith's graduate classes at Penn were rigorous. As I wrote in The Handbook of the Study of Play (Meckley, 2015), the student was expected to undertake a full immersion in theories on play across at least ten disciplines. In the graduate course I completed entitled 'Play, Games, Toys, and Sports in Human Development,' the required readings (41articles and 2 books) spanned disciplines including biology and ethology, communication, education, mass media, narrative studies, psychology, folklore, sociology, anthropology, sociolinguistics, leisure studies, and psychiatry. In this one course, Brian required the student to complete ten assignments, including research. But my learning as Brian's student was enriched by the time, effort, and expectations of my mentor.

Brian was an excellent teacher. I observed that for every class and for every conference presentation, Brian had prepared notes (lesson plans one could say). His teacher training in New Zealand at Wellington College served him well.

Brian was also an energetic and exuberant teacher. His classes were organized and full of ideas and theories from his work and from others' work. He talked quickly and went on diverse paths through multiple and varied fields. Often I could not write fast enough. I will never forget the day, in the middle of a stimulating lecture in front of a large class, when Brian stopped in mid-sentence, looked directly at me, and said "Alice, you need to leave right now or you will miss your train." He was right. I barely made the last train out of Philadelphia that day. How considerate! And I know that he demonstrated the same level of caring for all of his doctoral students.

As my thesis advisor, Brian continued to be caring and empathetic of my personal life which involved working full time in the day; parenting young children; and working into the night as a doctoral student. He suggested that I complete dissertation research with another student, also a parent with young children, which did not happen. He arranged for me to meet for thesis advisement at his home, which was less of a commute, and involved the added bonus of a chat with Shirley, his wife, who usually made lunch and showed me her beautiful handmade quilts. Although a rigorous mentor, Brian provided me with all the ideas, resources, and prodding I needed to finish my dissertation just before he retired.

Brian knew first-hand about juggling an active family and a prolific career of research, writing, publishing, teaching, and advising students. And he consistently maintained the balance of family and work with his playful pursuits. He managed this feat his whole life with Shirley, five children, and ten grandchildren. Due to Brian's modeling, I became a better professor, caring more fully about my students and their lives outside the classroom.

Brian lived the playfulness he studied. Full of vitality, flexibility and perseverance, Brian himself demonstrated his first and most durable theory of play which was play as a viability variable and play as a commitment variable (Sutton-Smith, 2008a). He was motivated to live and study with verve. Essentially for any person, play makes life worth living. 
Brian's second play theory involved cultural aspects of play, the study of play contexts (Sutton-Smith, 2008a). Culture is the context in which adults and children socially create and manage play (Meckley, 1994). He believed playing is what people do when they create culture. A cultural theory of play then involves the study of games, festivals, narratives, toys, and socialization, all important research areas for Brian who wrote extensively on these cultural aspects of play (Meckley, 2015).

Brian's most recent and most complex theory about play, often referred to as Play as Emotional Survival (Sutton-Smith, 2007; Sutton-Smith, 2012), occupied his thinking and writing for the final 15 years of his life. This theory highlighted the importance of emotions in most forms of play (Sutton-Smith, 2001).

Brian's life and career are inspiring and creative. In The Manifesto: A Guide for Developing a Creative Career (2002), E. Paul Torrance explained that a creative career means that the person is not afraid to fall in love with something and pursue it with intensity; is understanding and proud of their best strengths ... practicing, developing, exploiting, and enjoying these abilities; and the person does what they love and can do well in spite of others' expectations. Brian's life journey was full of creativity, humor and passion. Brian was a seriously playful and joyful scholar.

I will conclude with some of Brian's own concluding remarks. In The Future of Play Theory (1995) he advises the student that, "it takes considerable courage to continue to study a subject matter that most other scholars do not appreciate and which will often be, in consequence, of no help in their own personal academic advancement" (p. 293). Therefore, Brian Sutton-Smith often affirmed at the end of his writings the charge to the person studying and writing about play to find the "joy of the journey" (Sutton-Smith, 2005, Part V) and to know that "it is possible to have fun" (Sutton-Smith, 2011).

Strive to live your life in the spirit of play as did Brian Sutton-Smith.

\section{Anna Beresin - Meeting Brian in a Book}

In the mid 1980s, I stumbled upon a book in the Harvard Coop Bookstore entitled Toys as Culture (1986), and decided on the spot to see about studying with its author, Brian SuttonSmith. Brian was at the University of Pennsylvania, and I soon moved to Philadelphia to study with him at the Graduate School of Education. As Brian was jointly appointed in the Psychology of Education and in the Folklore Department in the School of Arts and Sciences, and as I was there to apprentice with him, the university graciously allowed me to complete a double PhD in both departments, focusing on children's folklore.

As I met Brian in a book, it seems most fitting to share with you stories from one of his own, a now out of print novel he wrote when he was a young teacher of children in his native New Zealand. Smitty Does a Bunk (1961) was written to entice his students to read, and as it was published with plenty of slang and 'misbehavior,' its publication was the source of considerable controversy. To 'do a bunk' meant to run away from home, and the story features the brothers Brin and Smitty, a slightly veiled reference to Brian and his own big brother. Brin and Smitty plan staying out all night with their friend Gormie. Here Brian shows his affection for Piagetian child psychology:

"What's it like being out all night?" said Gormie.

"It's just like not going to bed. That's all."

"How?"

“Well you know what it's like not going to bed on Guy Fawkes' night don't you?"

"Yea."

"Well, it's just like that, only it keeps on being like that all the time. It doesn't stop when you go to bed cause you don't go to bed." 
"But what happens to the night?"

"What night?"

"The night you lose."

"What night you lose?"

"Well, if you don't go to bed, you've never had any night have you eh? And that means it's really all day right through from breakfast time on day till breakfast time the next day, doesn't it, eh? And where's the night gone, eh?"

"Gone? It hasn't gone anywhere."

"But it must of. If you haven't had the night, you must have lost it. And if you've lost it. Where's it gone?"

"But it hasn't gone."

"It must of. There's three hundred and something or other days in a year and three hundred and something or other nights without the one you lost. Where did it go?"

"Aw, you're just mad. What a drip of a question. It's still there of course."

"I know!"

"You know what?"

"Every night you lose must mean you're a night younger. So if you had a night out as you reckon you had, then you should be a night younger than you really are.'

"Aw you're screwy."

Brian loved the ritualized rhyming of folklore and the spirit of freedom associated with peer culture. His storytelling mirrors the rhythmic singing in another episode:

"Two more weeks and we shall be

Out of the gates of misery."

And everybody ran away down the road, and the little girls ran away down the road with everyone else, and the line of standard six boys with their arms joined together ran away down the road with everyone else. And some went this way and some went that, but wherever anybody went, everybody knew that the holidays had come. Two big WHOLE weeks with everyday all full up with holiday. So FULL UP with holiday that there was no room for anything else. So full up with holiday that it seemed to make the air thick. You could smell it. Just as it if were full of fish and chips. And when they walked and ran and hopped and skipped and just went down the roads from school, everybody was walking and running and hopping and skipping in air that was thick THICK with all the things that everybody was going to do. . . corker big long days, football up at the park, kicks at the goalposts (if they were up), coffee buns for dinner, flying kites, making hairy-buzzers, tracking each other down in the pines and the Flicks on wet days. You could almost eat all the things to do out of the middle of the thick air.

But Smitty went home a bit more quietly than everybody else cause he was thinking about his special idea as usual. He'd thought about it for a long time now."

Brian loved trouble. It was the seed of critical thinking, and troublemakers were the most fun and made for the best fieldwork. My favorite Smitty adventure involves our three heroes attempting to sneak into the local zoo.

Smitty was down on his knees just about to crawl after him when all of a sudden the bushes nearby gave a big heave and a man rushed out on them.

He had a big black hat pulled down over his face.

"Hey! there you boy. What do you think you're doing?" cried the man. Gormie took a frightened look back from the other side of the gate and pelted off down the path without a word. 
"Nothing," stammered Smitty scrambling to his feet again.

"Yes, you were, boy," shouted the man looking at Smitty with a wild screwed up face.

One of his cheeks kept jerking up under his left eye just as though it was going to

wink. But it didn't. Instead the eye just glared out at them, glared and glared while his face twitched and jumped.

"No Sir," muttered Smitty. And then the man pulled a black notebook out of his

pocket and took a pencil from the rim of his black hat.

"What's your name? What's your name? he jerked out.

"Name?" said Smitty, "Name? Ah ah ah. .."

"What's your name boy?"

"Na names?" said Smitty.

"NAMES!"

"All of them?" said Smitty. And the man's eyes grew wilder and wilder and his face twitched faster and faster. His teeth showed and there was dribble on his lips. Brin moved a little behind Smitty. "Both names?" said Smitty again.

"Your NAMES!" said the man.

"Honkus," said Smitty suddenly.

"WHAT?"

"Honkus Piacky. Honkus Spang Piacky."

"Spell it."

"H-o-n-k-u-s, Spang, Sp-ang, Pi-acky, P-i-acky." The man paused a moment, glared at Smitty, and then rubbing his ink pencil on his tongue he scribbled it all down in his book.

"And yours?" he hissed turning on Brin his face jerking faster than ever.

"Brin, Brin Smith."

"THE TRUTH."

"It-it-it-is the truth," stuttered Brin.

"I want only TRUE NAMES," he shouted again. "Yes, ONLY TRUE NAMES WILL BE GOOD ENOUGH, enough, enough enough."

"Brin Smith," said Brin again."

Brian, the scholar, particularly loved Rabelais, that 500 year-old writer of Gargantua and Pantagruel, or as I like to think of them, as the early versions of Cookie Monster. Although these words were written by French scholar Denis Saurat as an introduction to Rabelais' text, every word rings true for Brian:

As for his mind, there is none better: he can argue with the subtlest ... On education, we still go to him; and his criticism of the education of his day still largely holds good against ours today. Against useless erudition he is splendid ... His enthusiasm for science is still an inspiration ... Look at the absurdity of things and of men: and do not take it seriously: laugh. (Saurat, 1945, iv.)

As for his mind, there is none better.

\section{Tom Henricks - Brian Sutton-Smith's Legacy for Play Studies: 10 Themes}

We gather here to remember Brian Sutton-Smith and to ponder his legacy.

There are, it should be noted, different ways of thinking about the term "legacy". One way, perhaps the most familiar, is to understand legacy as a social matter. An individual's legacy resides in the persons he or she has met and influenced. Professors - and Sutton-Smith was a wonderful example of this - communicate with students, colleagues, associates, and the public at large. Those "legates" or "legions" carry the teacher's ideas, models of inquiry, and 
habits of being into their own social circles, where those approaches are practised, discussed, and refined. The professor lives on in this very important way.

A second way of understanding legacy - and the approach I follow here - is to consider this matter abstractly, or culturally. Professors - and here again Sutton-Smith shines - offer their writings to the academic and popular press. Through those vehicles, thousands of people who will never meet the writer consider these formulations. Indeed, generations to come will have much the same opportunities to read, reflect, and respond as those living now. In other words, it is the ideas themselves that prosper and thicken in their implications. What are, at least in my judgment, some of the most important ideas of Professor SuttonSmith? I discuss below ten of these, many of which have already changed the field of play studies and others which should be heeded carefully as that field advances.

\section{Studying play properly requires many academic perspectives}

Sutton-Smith never confined himself to one way of looking at his elusive subject. Although originally a student of education in New Zealand, he fused this with later researches in developmental and comparative psychology and, especially, folklore. He understood that play is something people across the world do, but they do it in their own, culturally modified, ways. And he recognized that because play is universal, there must be some biological fundament that urges this activity and that links human creativity to the romping of other creatures.

This ecumenical spirit is expressed most fully in his classic work, The Ambiguity of Play (Sutton-Smith, 1997). That book, as readers may recall, addresses many issues; but it is especially a recognition that many disciplines have contributed to our understanding of what play is and can be. Play may have its proper home in the fields of early childhood development, psychology, and education. But coming to terms with play also means studying the offerings of anthropology and sociology, history, folklore, literary theory, philosophy, and recreation. There are emerging disciplines, like media and performance studies. And, always, one must attend to what biologists, neuroscientists, and scholars of animal behavior are saying about the groundwork of human possibility. Without this multidisciplinary sensitivity, scholarly understandings of play remain partial.

\section{We should combine the theoretical, empirical, and applied}

As there are many disciplines, so there are different avenues of scholarly commitment within each of these. Some of us - by training, but perhaps more by inclination - are theorists. Others have an empirical spirit. Still others stress the importance of doing real work in the real world and, by consequence, changing people's lives.

Most of us who study play find that one of these styles suits us best. Sutton-Smith was exceptional in his ability to transcend these limitations. Because of that, it is common for play scholars to have their own "Brian," who speaks to their highly particular commitments. A theorist like me is interested especially in Sutton-Smith's multi-faceted - and continually evolving - accounts of play's nature and implications. But he was also an empiricist who spent countless hours observing children and recording their stories, rhymes, and jokes. He was keen to show that those accounts do not always square with what adults - or indeed, theorists of play - would have those children say.

Sutton-Smith was equally an advocate and practitioner. An educationalist by training, he supported different styles of play, commented on the proper roles of adults in those processes and, more generally, advocated the right of all children to explore their own development in ways of their choosing. He and his wife and colleague Shirley consulted with toy makers; advised parents; fought against excessive drilling, testing and regimented recreation in schools; commented on playgrounds; and supported rising professions like playwork. 


\section{Acknowledge the value - and the limitations - of play's "rhetorics"}

In The Ambiguity of Play (1997), Sutton-Smith articulates his view that play scholars tend to operate within distinctive academic camps, which should be recognized as ideologies or "rhetorics." These camps are marked less by disciplinary divisions - such as psychology being opposed to history or sociology - than they are by the inhabitants' shared belief that a certain way of studying play - and making policy recommendations on that basis - is best. Commonly, those beliefs are never examined in a rigorous way. Sometimes, the believers are simply unaware of other traditions.

In his book, Sutton-Smith describes seven of these ideologies. Most attention is given to what is surely the dominant view in play studies: play is a vehicle for the development or "progress" of young humans and animals. Although he questions some of the theoretical and empirical underpinnings of this perspective that play always advances creaturely capability, he does not disparage it. Instead, he stresses that there are other ways of studying play's meanings.

Some of those ways, like the rhetoric of progress, are common among scholars who focus on play in modern societies. In that light, he describes a second theme: childhood "imagination" and fantasy. Play, for many scholars, is a protected setting where people explore cognitive, moral, and emotional themes. Closely related to this is a third rhetoric he calls the "self." Such a view stresses that play helps people realize themselves as persons, not in the interiors of the mind but in real-life encounters with other persons and objects.

There are also rhetorics favored by those who study traditional societies and by others who ponder play's darker, more deviant expressions. In such contexts, play may be seen as an encounter with "fate," where people confront forces they cannot control. So we gamble, wilfully risk our safety in drug-based or sexual escapades, and court physical danger. Alternately, play may be described by a fifth theme: foolishness or "frivolity." When we are silly, we undermine public standards for thought, feeling, and behavior. Cultural patterns and social relations - are dissembled and reassembled.

Still different is the rhetoric that Huizinga stressed: play is about social competition or "power." Commonly, this competition is fair to a degree that most of us would advocate, but play occasionally turns into activities that are manipulative, abusive, or mean. Although traditional societies sometimes honor violent or exploitative forms of display, they also exhibit a seventh and final pattern: "community identity." While scholars of modernity emphasize the rise of the individual, in play as elsewhere, anthropologists and historians demonstrate how communities, transcending their members and even the generations, are built through play.

Sutton-Smith's thesis is that play operates in different personal, social, and cultural contexts and, indeed, within these contexts, functions in different ways. The challenge for play studies is to accommodate all these perspectives.

\section{Play can be rebellious and disorderly}

Most writers on play, I would venture to say, are interested in that subject because they see play as an opportunity for people to exhibit - and become - their better selves. The ideal society is one where individuals follow agreed-upon rules, cooperate, and support one other. Play cultivates these pro-social tendencies. More than that, it prizes creativity, especially of the sort that "constructs" the world. Typically, scholars describe play-worlds as places where people build things and then live amidst their creations peaceably. Less attention is given to the ways in which players tear things down.

In a noted essay written with Diana Kelly-Byrne, Sutton-Smith (1984a) decried this "idealization" of play. To be sure, much play is constructive, but some is destructive. Play 
prizes cooperation (as Huizinga said) but it also celebrates competition (as Huizinga said). Much play is indeed progressive, but other forms seem regressive. In other words, we are not always those "better selves" when we play. Sometimes we are naughty and disrespectful. In Sutton-Smith's view, these are not qualities for which the player must apologize. Rebellion essentially, testing the boundaries of the permissible - is as critical for developing individuals and groups as compliance is.

Furthermore, it is rarely the case that play is only one thing and not its opposite - for example, an event's being entirely spontaneous and creative and not rule-bound. In another essay, again with Kelly-Byrne, Sutton-Smith (1984b) describes a fundamental "bi-polarity" in theories of play. Play is, simultaneously, "equilibrating" and "disequilibrating."

Ordinarily, play has rules and features moral order. But it also features tension, stress, and conflict. Certainly, some play activities seem more tension-filled than others. But play almost always features a steady agreement - if only by the individual herself - about what is to be done. Within that framework, the possibilities of disorder - and its resolution - are explored (see also Henricks, 2009).

\section{Play is interactive, or dialectical}

Sutton-Smith once confessed to me that one of the proudest moments of his early career occurred when he challenged Piaget about the latter's influential theory of play (SuttonSmith, 1966). Piaget, it may be recalled, argued that children's more basic forms of play should be seen as "pure assimilation," a pattern in which individuals try to impose their own visions for activity on the world (Piaget, 1962 p. 89). That practicing of "schemas" - as when a child wilfully jumps back and forth across a small stream - is done for the sheer pleasure of doing-and-achieving. Through repetition children expand, and gain confidence in, their ability-sets.

Sutton-Smith understood that play can be practice. But he stressed that play also features acts of adjustment or re-thinking based on how the world responds to our schemas. In other words, play features "accommodation" (the reassessment process that Piaget described as the opposite pole of mental activity) as much as it does assimilation. Players discover new possibilities in situations at the same time that they engrave the tried-and-true. And these new possibilities arise through interactions, or patterns of give-and-take.

For such reasons, Sutton-Smith (1978) characterized his approach as "dialectical." That exchange process does not seek to end dispute or alleviate tension. Instead, it celebrates these instabilities. And out of this ferment, play's meanings arise.

\section{Play is for all ages}

Encouraged by the "play-as-progress" rhetoric, most play scholars maintain a deep commitment to the development and well-being of children, and within that group, young children. Kids - like the young of other species - are rapidly expanding their abilities in ways that adults can only envy. They are developing new understandings and determining the usefulness of these. They are learning moral judgment, sometimes painfully. There are emotions to be experienced - and managed. By increments, important comprehensions of selfhood emerge. Play is the laboratory where we explore, under controlled conditions, what we can and cannot do.

Sutton-Smith himself was committed to the education of young children. His studies of play center on the perils and prospects of those early stages of life. But he was also drawn to anthropological, historical, and sociological accounts that focus on the meanings of public play for adults. He was interested in the play-of-meaning in literature and philosophy. As he discussed this issue in The Ambiguity of Play (1997 p.75), his work "takes for granted that sports, festivals, and contests are indeed matters of play and that the play concept is not to be 
applied only to children." Music, art, and dance are equally occasions of creative personal expression. Players come from every age group. And the principal consequence of play - to awaken the self to the possibilities of living - is surely universal.

\section{It's about the variability!}

As Sutton-Smith (2008a) recalled in an essay about his career, his theories moved through three stages. The first of these stages concentrated on play as a "viability variable" (p.90). Witnessing the street games, stories, jokes, and rhymes of children revealed to him that play is less about sing-song bonding than it is about spunky improvisation and rebellion. Misbehaving, and creating more generally, is functional; for it expands behavioral repertoires and emboldens the perpetrators. Such skills may be useful in moments to come, not only those that are anticipated, but also those that are not.

In the second theoretical stage he stressed "culturally relative play forms" (p.99). Play, as he learned from anthropologists, is shaped by cultural as well as psychological and biological factors. Different societies impose different kinds of challenges for their members. When children play games, they materialize those challenges and shape useful responses to them. That general approach was termed the "conflict-enculturation" thesis (Roberts and Sutton-Smith, 1962). It is less about learning "values" or "habits" than it is about confronting salient issues.

The third and final stage featured an attempt to see play as a "co-evolutionary multiplex of functions" (Sutton-Smith, 2008a p.111). In essence, that mature writing sought to integrate the themes of body, brain, and culture described above. Play was understood to advance both individuals and the species itself. The play of other creatures was seen as foundational to our own. Human play was claimed to be adaptive at many different levels: from the most basic forms of physical positioning through psychological and social considerations to encounters with complicated cultural scripts. All are contexts within which people confront issues and find their places.

As the reader should note, Sutton-Smith never rejected his initial theory but instead built off it. Concerns about cultural variability and multiple functions are essentially expansions of the play studies lens. People do not play to establish precise behaviors but to explore possible responses to many issues, tensions, or "dualities" (Sutton-Smith, 2008a p.114). Variability remains central. In the final chapter of The Ambiguity of Play, he makes this plain: "So in conclusion, I have presented here the view that variability is the key to play and that structurally play is characterized by quirkiness, redundancy, and flexibility" (SuttonSmith, 1997 p.229). Once again, play broadens rather than narrows patterns of response.

\section{Play expresses our most basic emotional yearnings}

There is another important issue, which Sutton-Smith was working on during his last years. Play speaks, or so he claimed, to something very basic within us: our feelings about ourselves and about our placement in situations. Earlier scholarship, including much of Sutton-Smith's, focused on play as an occasion to establish cognitions of how the world operates, evaluate and refine values, and hone useful skills. But humans are not calculating machines. We operate with deeply established emotions, patterns of awareness and expression that indicate to others what we are preparing to do and indeed, that clarify those intentions to ourselves.

From Schiller onward, scholars have recognized that play is satisfying, expressive behavior. When we play, we experience and display many dimensions of ourselves. Our playful recognitions-and-responses simultaneously unite feelings with thoughts, moral judgments, and skills. We are urged in one direction and then another by these orientations. 
Although most have depicted emotions as by-products or rewards for play, Sutton-Smith took the different line that emotions are sources - and then sounding boards - for the activities that follow. In that context, players seek out activities that will bring to the surface fundamental emotions. They create scenarios that keep these feelings in play; through their actions, the players show their ability to confront and control them. To the extent that these activities are successful, people convert what are usually thought to be negative feelings - like disgust, fear, or shame - into positive ones. Good play is that which elevates these concerns effectively and manages them well.

As one part of his theory, Sutton-Smith sought to link major forms or types of play (identified with his seven rhetorics) to very basic emotions like fear, anger, sadness, happiness, disgust, surprise, and shame. Different play activities - such as visiting haunted houses or telling 'gross' jokes - can be seen as opportunities to revisit experiences that have been fundamental to the survival of our species. Play keeps us emotionally ready, or sharp, through this reawakening of commitments. And more complicated social and cultural forms of play perform similar functions for the "secondary" emotions that are established on this basis and cultivated through social learning (Sutton-Smith, 2008a p.114).

Although illness prevented Sutton-Smith from developing these themes fully, his challenge to subsequent generations of play scholars remains. Play celebrates what is optimistic in humans. It converts hesitance and disability into their opposites. What role does emotion play in these processes?

\section{Play is pluralistic, paradoxical, and ambiguous.}

Sutton-Smith opposed narrow visions of what play "is" or "means." In his view, play always takes many forms and means many things. Some of those things even seem to be opposites. Thus, as we have seen, play may be simultaneously rule-bound and spontaneous, orderly and disorderly, rebellious and compliant. It is entirely momentary in its circumstances and commitments and yet is universal in its appeal and in its enrichment of human life.

It is also the case that different people 'get' different meanings out of play experiences. At any rate, there are different roles in play: leaders and followers, parents and children, winners and losers, creators and destroyers. Some players comply while others rebel. People alternate their roles. Part of play's charm is the variety of experiences that it induces.

Toward the end of his career, Sutton-Smith (1997, p. 142) aligned his view with Mikhail Bakhtin's theory of the 'dialogue' that occurs in novels and other cultural forms. For Bakhtin (1981) there is a plurality of voices that shapes the character of events. The public imagination - and the private one that participates in this - is fed from many sources. There is always more meaning - professions, allusions, contradictions, confusions, and such - than anyone can say. It is out of that ferment that play's meanings arise.

Sutton-Smith's classic work is titled The Ambiguity of Play for good reason. His scholarship reminds us that we should not expect play to be only of one style or to be narrow in its meanings. Those who harbor such beliefs will find that play's character and importance eludes them.

\section{The task is never finished}

There is a character in Virginia Woolf's To the Lighthouse who is driven to know all he can about his chosen field of inquiry. To describe Mr. Ramsay (often thought to represent the author's own historian-father), she uses the imagery of the alphabet (Woolf, 1955, pp. 53-56). In his quest for philosophical knowledge, the character has reached "Q," farther than most people can imagine. He is driven to stand on the next step, "R." Is "S" possible? One person in a generation, or so he believes, reaches " $Z$." 
More considerate in every way than Woolf's Mr. Ramsay, Brian Sutton-Smith was just as committed to learning all he could about his chosen subject: play. He read, observed, analyzed, and created voraciously. He worked his way through that particular alphabet farther perhaps than any other scholar has gone.

Yet, he was also clear that learning about play - like participating in play - is an opening rather than a closing of knowledge. Many people must be engaged in that inquiry. Many approaches must be welcomed. Theory, research, and practical applications are to be communicated and assessed widely. Brilliant scholars - like Professor Sutton-Smith - are to be acknowledged and consulted. But no single view is to be over-praised. The field of play studies advances through collective deliberation, creativity, and commitment.

\section{Michael Patte - Brian and the Association for the Study of Play (TASP)}

After the death of Brian-Sutton Smith, renowned $20^{\text {th }}$-century play scholar, a memorial symposium was organized to celebrate his remarkable life and contributions to the field of play at the $42^{\text {nd }}$ annual gathering of the Association for the Study of Play (TASP). My role on the panel was to reflect upon Brian's influence on TASP over the years, especially how he nurtured students and young scholars interested in studying the construct of play. To encapsulate the impact Brian had on the study of play throughout his storied life, I borrowed a phrase used by Bono, front man from the band $\mathrm{U} 2$, who when eulogizing the great American singer-song writer Johnny Cash said "In a garden full of weeds - the oak tree."

Although not a founding member of the Anthropological Association for the Study of Play, now the Association for the Study of Play (TASP), Brian played an active role in the association from its inception in the early 1970s through attending the annual meetings; editing the association's newsletter, proceedings, journals, and volumes; serving on the association's executive committee; serving as the association's president; offering conference presentations and keynote addresses; producing an impressive catalogue of scholarly writings; and introducing generations of students and young scholars to the association and hence the field of play.

Like many before me, The Ambiguity of Play (1997), thought to be Brian's seminal work, expanded my thinking about the very nature of play through examining his seven rhetorics (play as progress, play as fate, play as power, play as identity, play as imaginary, play as the self, play as frivolous). As a young play enthusiast trained in the field of education, my lens was hyper-focused on the rhetoric of play as progress, due in part to the marginalization of play I witnessed on a daily basis in the lives of children and my efforts to justify the importance of play to both teachers and parents. Thanks in part to Brian's influence, today my thinking, writing, and research focus about play is much broader in scope and sequence.

My first encounter with Brian was at the 2004 annual TASP conference in Atlanta. It was my first year as a university faculty member and I was sharing the results of an empirical study titled, All in a Day's Work: Children's views on play and work at the fifth grade level. I chose an informal roundtable format to share the preliminary results as I was new to academia and to TASP. To my surprise, several attendees visited my twenty-minute roundtable presentation. About halfway through the talk, an elderly gentleman got up from the table and walked out of the room. I assumed that he either lost interest or needed a bathroom break. To my surprise, a few minutes later, the gentleman returned with a Martini in hand. Throughout the presentation, participants asked thoughtful questions and offered sage advice about how the study could be strengthened. Their takeaway message to me as a young play scholar was resounding: it's ok to study play as it has great intrinsic and extrinsic value. Only after the presentation did I learn that the Martini man was Brian Sutton-Smith and from that very moment my professional home became TASP. 
In the years from 2004-2014 I got to know Brian on a more personal level through informal discussion over lunch and dinner at the annual TASP gatherings. Brian was also memorialized through fantastic stories shared by colleagues that became more embellished with each passing year. What truly endeared Brian to so many of his colleagues was the combination of his superior intellect and his self-deprecating nature. Brian was as likely to unravel the great mysteries of the universe as he was to make you piss your pants laughing from a bawdy joke. During the annual TASP gathering in 2010, the conference organizers attracted an impressive slate of keynote presenters including Brian Sutton-Smith, Joe Frost, and Stuart Brown, just to name a few. It is customary for keynote addresses not to be scheduled opposite concurrent sessions to provide all attendees the opportunity to partake in these featured sessions. However, due to a scheduling glitch, Brian's keynote titled Play as Emotional Survival was scheduled opposite several concurrent sessions. Soon after Brian's talk began, the program chair realized that none of the attendees were populating the concurrent sessions. So, the program chair interrupted Brian's talk to encourage audience members to visit the concurrent sessions taking place. Nobody left, and Brian continued his talk unfettered.

I was one of the lucky members of the audience that day to observe close up and first hand Brian's last keynote address at TASP. I assisted Brian during the presentation by advancing his overhead transparencies; to date, it is my greatest professional accomplishment. It was obvious in 2010 that Brian's health was failing and that he would soon no longer be able to make the yearly trek to TASP. The 2011 annual meeting of TASP at the Strong National Museum of Play in Rochester, New York, served as Brian's swan song. At that meeting Brian presented his former student Alice Meckley with the Brian Sutton-Smith play scholar award for her dedication to TASP over the years. It was a fitting tribute that Brian present the award named in his honor to one of his former students. Fraser Brown and I also interviewed Brian at the 2011 gathering in Rochester about his forthcoming book, Play as Emotional Survival. The interview, titled From the Streets of Wellington to the Ivy League - Reflecting on a lifetime of play, appears in Volume 1, Issue 1 of the International Journal of Play.

It was a personal and professional privilege to have known Brian Sutton-Smith even for the briefest of times. During Brian's memorial service in 2015, his family and friends celebrated a life well lived through touching stories and lifelong memories. I've learned a great deal from Brian over the years, but the most important lesson is that play is a messy, dirty, and bawdy endeavor that should be celebrated and never stifled or censored.

\section{Fraser Brown - the end of a life}

I first met Brian when I was asked to 'look after him' for a few days before he spoke at a National Playworkers Conference in the UK. I didn't really know what to expect. In the UK we tend to associate double-barrelled names with certain stereotypical characteristics - mostly not very positive. I knew him from his writing of course, but that just made the thought of trying to entertain him for a week even more intimidating. So it was with a fair amount of trepidation that I waited for him at the airport. I need not have worried. The wonderful man who arrived that day had no airs and graces at all. He was mischievous, funny and playful, yet with a mind as sharp as anyone I had ever met. He was instantly at ease with my whole family - my wife, my daughter, my ageing father-in-law and my one year old grand-daughter.

In the years that followed we became good friends, bonded together by our passion for the study of children's play, a love of sport, and a similar sense of humour. We played games, watched football matches and wrote together. I once helped him edit a complete draft of his 'final' book, albeit (and this was wonderfully typical of Brian) the next time I saw him, he 
had rewritten the whole thing. Brian contributed a chapter titled Beyond Ambiguity (2008b) to one of my books. This contained a summary of his thoughts about 'play as emotional survival', which was intended to be the title of his final work.

Towards the end of his life, I visited Brian in a care centre in Vermont. Although his health was fading, and his faculties were on the wane, he nevertheless retained the same basic nature that so many of us loved in him. Despite some confusing conversations, we were still able to share meals together, and go walking and enjoy the first signs of spring. In short, despite the lack of focus, Brian was still a joy to be with, just as he always had been.

When Brian finally left us there was a tangible sense of loss, and the tributes started pouring in. Here are a few of them:

There will never be another Brian Sutton-Smith. He was there at the beginning of TASP as well as for anyone who has engaged with the study of play and especially for anyone who wants to play. I think Brian embodied play which is why he was such an amazing person and also researcher. I feel privileged to have known him and to have learned from his work and to have benefited from his support and encouragement. Brian and play are synonymous in my view. He will be greatly missed but his playful presence in everything that he wrote and said will always be with us.

\section{Helen B Schwartzman}

He lived a very full life, played well and deeply and with great heart. I was moved by how, along with his deep intellect and breadth of knowledge, he shared, from time to time, such tender caring for his students. And when it came to those wine and cheese socials for which TASP was founded (OK, there were other reasons), he was a firebreathing delight to all. Party on, Brian. Cheers!

Bernie De Koven

Brian's work guided my teaching and research for more than three decades. He was so supportive of my work, and wrote beautiful and persuasive letters for me. I always think of him fondly, and with admiration. When I retired and moved, his were the books that I kept.

Stuart Reifel

The world is less playful with Brian gone. Brian gave the single most brilliant conference presentation I've ever heard, on the ambiguities of play. I think it was at the joint TASP meeting in Baton Rouge in 1983. The contents have faded away over 30 years, but not the wonder of his presentation. Brian didn't romanticize play-he knew it could be ugly, cruel, and nasty, like any other open aspect of the human condition.

Rob Lavenda

And I think this observation is perhaps the most appropriate:

It's been said that we all die twice - once when we take our last breath and once when the last person speaks our name. Brian's work and the friendships he developed ensure that his name will be spoken for a very long time.

David Kuschner 


\section{Notes on the Contributors}

Alice M. Meckley is Professor of Early Childhood Education Emerita, Millersville University, Pennsylvania. She is a teacher, scholar, and consultant on play and children. As a professor of early childhood education, Alice's passion and knowledge about children's play earned her international lectureships and media appearances. As a scholar, a highlight of her career was researching and writing about young children's social play under the mentorship of Brian Sutton-Smith. Her article, 'A Student's Guide for Understanding Play Through the Theories of Brian Sutton-Smith' (Meckley, 2015) has recently been published in The Handbook for the Study of Play (Johnson et al, 2015). Alice is an ardent TASPian.

Anna Beresin is Professor of Liberal Arts at the University of the Arts in Philadelphia, and Co-Director of NEUARTS, Neighborhood Engagement at the University of the Arts. Her books include Recess Battles: Playing, Fighting, and Storytelling (2010) and The Art of Play: Recess and the Practice of Invention. Brian Sutton-Smith was her thesis advisor at the University of Pennsylvania, where she earned two doctorates: one in folklore, and one in the psychology of education. She has a book in press on dance games, and is currently filming gorilla play in zoos. See recessbattles.com; recessaccess.org; or http://www.uarts.edu/academics/neuarts-neighborhood-engagement-uarts.

Thomas Henricks is Danieley Professor of Sociology at Elon University. He is the author of numerous writings on play, many of which have appeared in The American Journal of Play and Play and Culture Studies. His books include Disputed Pleasures: Sport and Society in Preindustrial England; Play Reconsidered: Sociological Perspectives on Human Expression; and Selves, Societies, and Emotions: Understanding the Pathways of Experience. Another book, Play and the Human Condition, was published in 2015. He is also a co-editor of the new Handbook of the Study of Play (2014). He serves on the editorial boards of the American Journal of Play and the International Journal of Play.

Michael M. Patte is a Professor of Teaching and Learning at Bloomsburg University. During his 25-year career he has developed an interest in the fields of creativity, child development, and play and has shared his scholarship through publications, international and national conference presentations, and advocacy projects. His latest co-edited book is International Perspectives on Children's Play. Dr. Patte is a Distinguished Fulbright Scholar, co-editor of the International Journal of Play, past president of The Association for the Study of Play, board member of The International Council for Children's Play, and a member of the Pennsylvania Governor's Early Learning Council.

Fraser Brown, who chaired the Panel, is the first Professor of Playwork in the UK. He is programme leader for the BA (Hons) Playwork degree at Leeds Beckett University, and specialist link tutor for their postgraduate play therapy courses. Before joining the University he managed a wide range of playwork projects in both the statutory and independent sectors. He is well-known for his therapeutic playwork with abused and neglected children. He is coEditor of the International Journal of Play, and his recent publications include 101 Stories of Children Playing (2014); Rethinking Children's Play (2013) (with Michael Patte); and Foundations of Playwork (2008) 


\section{References}

Bakhtin, M. (1981). The Dialogic Imagination. M. Holquist and C. Emerson (Trans.). Austin, TX: University of Texas Press.

Beresin, A. (2010) Recess Battles: Playing, Fighting, and Storytelling. University Press of Mississippi.

Beresin, A. (2014) The Art of Play: Recess and the Practice of Invention. Temple University Press, USA

Brown, F. (2014) Play and Playwork: 101 Stories of Children Playing. Maidenhead: Open University Press

Brown, F. and Patte, M. (2012) Rethinking Children's Play. London: Bloomsbury Academic Brown, F. \& Taylor, C. (2008) Foundations of Playwork. Maidenhead: Open University Press

Henricks, T. (1991) Disputed Pleasures: Sport and Society in Preindustrial England; Westport, CT: Greenwood Press

Henricks, T. (2006) Play Reconsidered: Sociological Perspectives on Human Expression; University of Illinois Press, USA

Henricks, T. (2009). Orderly and Disorderly Play: A Comparison. American Journal of Play. 2(1): 12-40.

Henricks, T. (2012) Selves, Societies, and Emotions: Understanding the Pathways of Experience. Abingdon: Taylor and Francis

Henricks, T. (2016) Play and the Human Condition. University of Illinois Press, USA J. E. Johnson, S. G. Eberle, T. S. Henricks, \& D. Kuschner (Eds.) (2015) The Handbook of the Study of Play. Lanham, MD: Rowman \& Littlefield.

Meckley, Alice. M. (1994). The Social Construction of Young Children's Play. (Doctoral dissertation) Retrieved from UMI Dissertation Service. (Order No. 9427578).

Meckley, Alice. M. (2015). A student's guide for understanding play through the theories of Brian Sutton-Smith. In: J. E. Johnson, S. G. Eberle, T. S. Henricks, \& D. Kuschner (Eds.), The Handbook of the Study of Play (pp. 393-405). Lanham, MD: Rowman \& Littlefield.

Patte, M., Roopnarine, J. Johnson, J. and Kuschner, D. (2015). International Perspectives on Children's Play. Maidenhead: Open University Press

Piaget, J. (1962) Play Dreams and Imitation in Childhood. London: Routledge \& Kegan Paul.

Roberts, J. and Sutton-Smith, B. (1962). Child training and game involvement. Ethnology 1(2): 166-185.

Saurat, D. (1945) "Introduction.” In: Gargantua and Pantagruel by Francis Rabelais. London: John Westhouse.

Sutton-Smith, B. (1961) Smitty Does a Bunk. Wellington, New Zealand: Price Milburn.

Sutton-Smith, B. (1966). Piaget on Play: A critique. Psychological Review 73(1): 104-110.

Sutton-Smith, B. (1978). The Dialectics of Play. In: F. Landry and W. Oban (Eds.) Physical Activity and Human Well-being. Miami: Symposia Specialists. 
Sutton-Smith, B. (1986). Toys as Culture. New York: Gardner Press.

Sutton-Smith, B. (1995). Conclusion: The Persuasive Rhetorics of Play. In: A. D. Pelligrini (Ed.), The Future of Play Theory: A Multidisciplinary Inquiry into the Contributions of Brian Sutton-Smith (pp. 275-295). Albany , NY: State University of New York Press.

Sutton-Smith, B. (1997) The Ambiguity of Play, Cambridge: Harvard University Press.

Sutton-Smith, B. (2001). Emotional breaches in play and narrative. In: Goncu A. \& E. L. Klein (Eds.) Children in Play, Story, and School (pp. 161- 176). New York: Guilford Publications.

Sutton-Smith, B. (2005). Introduction to Part V . In: F. McMahon, D. Lytle, \& B. SuttonSmith (Eds.), Play: An Interdisciplinary Synthesis (pp. 291-293). Lanham, MD: University Press of America.

Sutton-Smith, B. (2007). Play as Emotional Survival. Keynote Address at IPA-TASP Joint Annual Conference, Strong National Museum of Play, Rochester, NY, April 27, 2007.

Sutton-Smith, B. (2008a). Play Theory: A Personal Journey and New Thoughts. American Journal of Play, 1, No. 1, 80-123.

Sutton-Smith, B. (2008b). Beyond ambiguity. In: Brown, F. \& Taylor, C. (2008) Foundations of Playwork. Maidenhead: Open University Press

Sutton-Smith, B. (2010). Play as Emotional Survival. Presentation at IPA-TASP Joint Annual Conference, Georgia State University, Atlanta, GA, March 10-13, 2010

Sutton-Smith, B. (2011). Play as Emotional Survival. Taped interview conducted at the Strong Museum of Play on April 29, 2011, edited and shown at 50th Anniversary IPA Conference in Cardiff, Wales on July 7, 2011.

Sutton-Smith, B. and Kelly-Byrne, D. (1984a). The Idealization of Play. In: P. Smith (Ed.) Play in Animals and Humans. (pp. 305-321). London: Basil Blackwell.

Sutton-Smith, B. and Kelly-Byrne, D. (1984b). The Phenomenon of Bipolarity in Play Theories. In: T. Yawkey and A. Pellegrini, (Eds.), Child's Play: Developmental and Applied. (pp. 29-47). Hillsdale, NJ: Lawrence Erlbaum.

Sutton-Smith, B., Brown, F. \& Patte, M. (2012). From the streets of Wellington to the Ivy League: Reflecting on a lifetime of play. International Journal of Play, 1 , No. 1, 6-15.

Torrance, E. P. (2002). The Manifesto: A Guide for Developing a Creative Career. Westport, CT: Ablex Publishing.

Woolf, V. (1927/1955). To the Lighthouse. New York: Harcourt, Brace and World. 